\title{
Development of ICT competence in high school students when teaching physics using digital laboratories
}

\author{
Viktor S. Kornilov' ${ }^{1}$, Irina A. Khanina ${ }^{2}$ \\ ${ }^{1}$ Moscow City University \\ 29 Sheremetyevskaya St, Moscow, 127521, Russian Federation \\ ${ }^{2}$ School No. 1494 of the City of Moscow \\ 1 Bolshaya Marfinskaya St, bldg. 5, Moscow, 127276, Russian Federation
}

\begin{abstract}
Problem and goal. Currently, to school education in Russia is given a lot of attention, both from state structures and from the Ministry of Education of the Russian Federation. Federal State Educational Standards of secondary general education of the Russian Federation define high requirements for the level of training of schoolchildren. In modern conditions of the information society, the school education system is designed to prepare students who form a fundamental system of subject knowledge in school disciplines, develop active, creative, critical, analytical thinking, and ICT competence. Today, those students successfully study at higher educational institutions in the educational process which are widely used information and communication technologies, self-learning and shaping system of fundamental knowledge in university disciplines which are based on modern achievements of world science.

Methodology. The development of ICT competence in high school students in teaching physics will depend on success rate of: improving the goals, objectives and content of teaching physics using digital laboratories together with educational Internet resources; implementing didactic principles of teaching physics using digital laboratories together with educational Internet resources, as well as forms, methods and tools for teaching physics using digital laboratories together with educational Internet resources.

Results. At laboratory workshops in physics in the conditions of using digital laboratories together with educational Internet resources, high school students acquire the skills to apply modern computer technologies. High school students gain experience in analyzing the results of experiments on various physical processes and phenomena using digital laboratories together with educational Internet resources. High school students acquire in-depth knowledge not only of subject knowledge in physics, but also of the potential of digital laboratories and information technologies. Such knowledge, skills and abilities allow high school students to develop ICT competence.

Conclusion. Developed in the process of teaching physics in the conditions of joint use of digital laboratories and educational Internet resources, ICT competence will allow high school students to be a successful student after graduation, entering a higher educational institution.
\end{abstract}

Key words: teaching physics to high school students, digital laboratories, educational electronic resources, ICT competence

(C) Kornilov V.S., Khanina I.A., 2020

(c) (i) This work is licensed under a Creative Commons Attribution 4.0 International License https://creativecommons.org/licenses/by/4.0/ 
Problem statement. One of the fundamental school disciplines is physics, which is widely used in teaching information technology (see, for example, [3; 9; $13 ; 17])$. In the process of teaching physics to schoolchildren, goals and tasks are implemented aimed at forming fundamental subject knowledge, developing creative abilities, acquiring skills and abilities to use information technologies to solve educational problems, and other goals and tasks.

The scientific and methodological aspects of the use of information technology in the teaching of physics to schoolchildren were devoted to their work by M.O. Verkhovtseva, E.V. Gerasimov, V.N. Davydov, A.I. Zabolotny, I.A. Zakharkin, N.Yu. Ivanova, O.V. Kuznetsova, N.P. Lytkina, M.A. Ogneva, V.G. Petrosyan, O.A. Povalyaev, I.Sh. Salikhov, E.A. Samoilova, N.Yu. Sokolova, E.P. Sukhankova, A.E. Tarchevsky, S.I. Telegin, L.V. Tishchenko, N.B. Fedorova, N.K. Hannanov, S.V. Khomenko, T.G. Yakovleva, and other authors (see, for example, $[2 ; 4 ; 5 ; 7 ; 10 ; 12 ; 15])$.

Currently, in teaching high school students physics, a variety of information technologies are used. Among such information technologies, various digital laboratories are widely popular, the use of which makes it easier for high school students to understand various physical phenomena. In addition, in digital laboratories, it's possible quickly configure to a specific laboratory practice and implement visualization of the data obtained during the experiment. Digital laboratories have convenient tools with which you can conduct various experiments, carry out appropriate analysis, test hypotheses and other possibilities.

Obviously, the use of digital laboratories in conjunction with educational Internet resources for teaching high school students physics requires the improvement of goals, content, forms, methods and means of training, the implementation of didactic principles of training using information technology.

Research methods. The use of digital laboratories in conjunction with educational Internet resources at laboratory workshops allows for interdisciplinary communication. As a result, high school students quickly master subject knowledge in physics.

Note some digital laboratories that are widely used in teaching physics to schoolchildren.

Digital labs "L-micro". These laboratories are designed to conduct a laboratory workshop in physics according to the scheme "two students - one computer" or "one student - one computer". Measurement tools are used comprehensively: analog and digital devices, a computer measuring system based on digital laboratory sensors. Separate modules can be used to assemble various plants for the experiment. The works included in the kit cover the topics studied in grade 10: "Mechanics", "Molecular Physics", "Thermodynamics", "Electrodynamics".

Digital laboratories "Archimedes". The laboratories are designed to conduct laboratory workshops in physics, chemistry, biology. These laboratories allow to provide automated data collection and processing, as well as display all stages of the experiment (instrument readings, tables, graphs). The experiments conducted during the laboratory workshop can be saved in real time and reproduced synchronously with their video recording. The wide range of sensors available makes it possible to implement laboratory workshops on many topics of school courses in physics, chemistry, and biology. 
Digital laboratories “Releon". The laboratories are designed to conduct laboratory workshops in many school subjects, including physics. These laboratories allow in the process of teaching physics to conduct not only laboratory experiments, but also to conduct laboratory and practical exercises. In these laboratories, direct connection of sensors to mobile tablets or computers is implemented, the built-in memory of digital sensors can store up to 10 laboratory experiments, it is possible to connect and disconnect sensors during a laboratory experiment without interrupting it and losing the results

The works of such authors as V.N. Davydov, S.I. Eskova, A.I. Zabolotny, O.V. Kuznetsova, M.A. Ogneva, M.A. Petrov, O.A. Povalyaev, N.Yu. Sokolova, N.B. Fedorova, S.V. Khomenko, N.K. Khannanov, T.G. Yakovleva and other authors are devoted to educational and methodological and scientific aspects of teaching physics to schoolchildren using digital laboratories (see, for example, $[4 ; 5 ; 7 ; 10$; $12 ; 15])$. The authors in their research pay attention to the organization of research mini-projects using a digital laboratory in high school physics lessons; the possibilities of using a digital laboratory for technical support of the choice of the subject of research activities of schoolchildren within various conceptual systems of natural sciences; the organization of experimental activities of schoolchildren in the conditions of using digital laboratories; the organization of extracurricular activities in physics in the main school with the use of a digital laboratory and other aspects.

Results and discussion. The methodological aspects of the development of ICT competence of schoolchildren are devoted to the work of many authors, among them: E.I. Bulin-Sokolova, V.F. Burmakina, V.E. Evdokimova, V.I. Kolesnikova, A.A. Kuznetsov, E.S. Polat, T.A. Rudchenko, A.L. Semenov, I.N. Falina, E.V. Kharlova, E.N. Khokhlova, I.A. Nesterova and other authors (see, for example, $[1 ; 6 ; 8$; $11 ; 16])$.

In their research, the authors highlight such aspects of ICT competence of schoolchildren as functional literacy in the field of information and communication technologies; skillful use of digital technologies, communication tools for accessing and managing information for solving educational tasks; understanding of the social significance of information and communication technologies, and other aspects. As an example, we give the opinion of V.I. Kolesnikova, who believes that "ICT competence is the ability of students to use information and communication technologies to access information, determine (identify) it, organize, process, evaluate, and create/produce and transmit/distribute it, which is sufficient to successfully live and work in an information society, in an economy that is based on knowledge" [8].

The joint use of digital laboratories and educational Internet resources in teaching physics to high school students, which allows them not only to form a system of fundamental subject knowledge, develop creative abilities, but also initiates the development of their ICT competence [14]. These circumstances require the development of methodological approaches and guidelines for conducting such laboratory workshops; the development of educational sites that support such training.

Conclusion. By participating in laboratory workshops in physics, high school students develop information culture, functional literacy in the field of digital technologies, and become more aware of the importance of digital laboratories in conducting laboratory physical experiments, thereby developing ICT competence. 


\section{References}

[1] Bulin-Sokolova EI, Hohlova EN, Rudchenko TA, Semenov AL. Formirovanie IKTkompetentnosti mladshih shkol'nikov [Formation of ICT competence of primary school children]: manual for teachers. Moscow: Prosveshchenie Publ.; 2012.

[2] Verhovceva MO. Uchebnyj fizicheskij eksperiment s ispol'zovaniem sovremennogo oborudovaniya kak sredstvo povysheniya effektivnosti uchebnogo processa [Educational physical experiment using modern equipment as a means of improving the effectiveness of the educational process]: dissertation of the doctor of pedagogical sciences. Saint Petersburg; 2015.

[3] Gel'fgat IM, Gendenshtejn LE, Kirik LA. Resheniya klyuchevyh zadach po fizike dlya profil'noj shkoly. 10-11 klassy [To address key challenges in physics for the profile of the school. Grades 10-11]. Moscow: Ileksa Publ.; 2016.

[4] Davydov VN. Ispol'zovanie cifrovoj laboratorii “Arhimed» dlya izucheniya effekta Rebindera na vneurochnyh zanyatiyah [Using the digital laboratory "Archimedes" to study the Rebinder effect in extracurricular classes]. Fizika v shkole [Physics at school]. 2019;(6):57-60.

[5] Davydov VN, Yakovleva TG. Ispol'zovanie cifrovoj laboratorii v uchebnoj proektnoj deyatel'nosti shkol'nikov [Use of digital laboratory in educational project activity of schoolchildren]. Fizika v shkole [Physics at school]. 2020;(8):198-202.

[6] Evdokimova VE. Formirovanie IKT-kompetentnosti mladshih shkol'nikov [Formation of ICT competence of junior schoolchildren]. Nauka i perspektivy [Science and prospects]. 2017;(1). Available from: http://docplayer.ru/68477507-Formirovanie-ikt-kompetentnostimladshih-shkolnikov.html (accessed: 14.10.2019).

[7] Zabolotnij AI, Hannanov NK. Ispol'zovanie cifrovoj laboratorii ot "Nauchnyh razvlechenij" v massovoj shkole i uchrezhdenii dopolnitel'nogo obrazovaniya [Use of digital laboratory from "Scientific entertainment" in mass school and institution of additional education]. Fizika $v$ shkole [Physics in school]. 2015;(8):37-45.

[8] Kolesnikova VI. IKT-kompetencii uchashchihsya kak osnova stanovleniya novogo kachestva obrazovaniya [ICT competence of students as the basis for the formation of a new quality of education]. Available from: https://gigabaza.ru/doc/23721.html (accessed: 14.10.2019).

[9] Larchenkova LA. Obrazovatel'nyj potencial uchebnyh fizicheskih zadach v sovremennoj shkole [Educational potential of educational physical tasks in modern school]: dissertation of the doctor of pedagogical sciences. Saint Petersburg; 2014.

[10] Povalyaev OA, Hannanov NK, Homenko SV. Cifrovaya laboratoriya po fizike. Bazovyj uroven' [Digital laboratory for physics. Basic level]: methodological guide for working with a set of equipment and software of the company "Nauchnye razvlecheniya". Moscow: MAKS-SPEJS; 2013.

[11] Podprogramma formirovaniya i razvitiya IKT-kompetentnosti obuchayushchihsya na stupeni osnovnogo obshchego obrazovaniya [Sub-program for the formation and development of ICT competence of students at the stage of basic general education]. Available from: http://av.disus.ru/programma/1997296-1-podprogramma-formirovaniyarazvitiya-ikt-kompetentnosti-obuchayuschihsya-stupeni-osnovnogo-obschego-obrazovaniyapodprogramma-formirovaniya-razv.php (accessed: 14.10.2019).

[12] Sokolova NYu. Issledovanie izotermicheskogo i adiabatnogo processov s ispol'zovaniem cifrovoj laboratorii [Research of isothermal and adiabatic processes using a digital laboratory]. Fizika v shkole [Physics at school]. 2018;(1):51-54.

[13] Tishchenko LV. Eksperimental'nyj praktikum po fizike kak sredstvo obucheniya starsheklassnikov resheniyu zadach (uglublennyj uroven') [Experimental workshop on physics as a means of teaching high school students to solve problems (advanced level)]. Azimut nauchnyh issledovanij: pedagogika i psihologiya [Azimut of scientific research: pedagogy and psychology]. 2018;7(2(23)):279-286.

[14] Federal'nyj gosudarstvennyj obrazovatel'nyj standart srednego obshchego obrazovaniya Rossijskoj Federacii (utverzhden Prikazom Minobrnauki Rossii ot 17 maya $2012 \mathrm{~g}$. No. 413. V red. Prikazov Minobrnauki Rossii ot 29.12.2014 No. 1645, ot 31.12.2015 
No. 1578, ot 29.06.2017 No. 613) [Federal State Educational Standard of Secondary General Education of the Russian Federation (approved by Order of the Ministry of Education and Science of the Russian Federation dated May 17, 2012 No. 413. In ed. Orders of the Ministry of Education and Science of the Russian Federation dated December 29, 2014 No. 1645, December 31, 2015 No. 1578, June 29, 2017 No. 613)]. Available from: https://classinform.ru/fgos/1.4-srednee-obshchee-obrazovanie-10-11class.html (accessed: 14.10.2019).

[15] Fedorova NB, Kuznecova OV, Ogneva MA. Metodika organizacii issledovatel'skogo miniproekta s ispol'zovaniem cifrovoj laboratorii kak sredstvo formirovaniya klyuchevyh kompetencij na urokah fiziki [Methodology for organizing a research mini-project using a digital laboratory as a means of forming key competencies in physics lessons]. Fizika $v$ shkole [Physics at school]. 2020;(1):38-43.

[16] Harlova EV. Formirovanie u obuchayushchihsya IKT-kompetentnosti [Formation of ICT competence in students]. Available from: https://pedsovet.su/publ/47-1-0-4671 (accessed: 14.10.2019).

[17] Kornilov VS, Lvova OV, Obolensky IS. Teaching physics students of humanitarianoriented groups in the Middle Years Programme (basic school) of the International Baccalaureate. RUDN Journal of Informatization in Education. 2019;16(3):270-280.

\title{
Article history:
}

Received: 15 November 2019

Accepted: 20 December 2019

\section{For citation:}

Kornilov VS, Khanina IA. Development of ICT competence in high school students when teaching physics using digital laboratories. RUDN Journal of Informatization in Education. 2020;17(2):146-152. http://dx.doi.org/10.22363/2312-8631-2020-17-2-146-152

\section{Bio notes:}

Viktor S. Kornilov, doctor of pedagogical sciences, candidate of physical and mathematical sciences, full professor, professor of the department of informatization of education of the Moscow City University. E-mail: vs_kornilov@mail.ru

Irina A. Khanina, computer science teacher at School No. 1494 of the City of Moscow. E-mail: irakhanina001@mail.ru

\section{Развитие ИКТ-компетентности у старшеклассников при обучении физике с использованием цифровых лабораторий}

\author{
В.С. Корнилов ${ }^{1}$, И.А. Ханина ${ }^{2}$ \\ ${ }^{1}$ Московский городской педагогический университет \\ Российская Федерация, 127521, Москва, ул. Шереметьевская, 29 \\ ${ }^{2}$ Школа № 1494 города Москвы
}

Российская Федераџия, 127276, Москва, ул. Большая Марфинская, д. 1, корп. 5

Аннотация. Проблема и цель. В настоящее время школьному образованию в России уделяется большое внимание государственными структурами, в том числе Министерством просвещения. ФГОС СОО предъявляют большие требования к уровню подготовки школь- 
ников. В современных условиях информационного общества система школьного образования призвана готовить школьников, формирующих фундаментальную систему предметных знаний по школьным дисциплинам, развивающих активное, творческое, критическое, аналитическое мышление, ИКТ-компетентность. Сегодня именно такие школьники успешно учатся в высших учебных заведениях, в учебном процессе которых широко применяются информационные и коммуникационные технологии, самостоятельно осваивая и формируя систему фундаментальных знаний по вузовским дисциплинам, содержания которых формируются на основе современных достижений мировой науки.

Методология. Развитие ИКТ-компетентности у старшеклассников при обучении физике будет зависеть от успешности совершенствования целей, задач и содержания обучения физике с использованием цифровых лабораторий совместно с образовательными Интернет-ресурсами; реализации дидактических принципов обучения физике с использованием цифровых лабораторий совместно с образовательными Интернет-ресурсами, а также форм, методов и средств обучения физике с использованием цифровых лабораторий совместно с образовательными Интернет-ресурсами.

Результаты. На лабораторных практикумах по физике в условиях применения цифровых лабораторий совместно с образовательными Интернет-ресурсами старшеклассники приобретают умения и навыки обращения с современными компьютерными технологиями, получают опыт анализа результатов экспериментов по различным физическим процессам и явлениям с использованием цифровых лабораторий совместно с образовательными Интернет-ресурсами, формируют глубокие знания не только по предметным знаниям по физике, но и о потенциале цифровых лабораторий, информационных технологиях, что в совокупности позволяет старшеклассникам развить ИКТ-компетентность.

Заключение. Развитая в процессе обучения физике в условиях совместного использования цифровых лабораторий и образовательных Интернет-ресурсов ИКТ-компетентность позволит старшеклассникам после окончания школы, поступив в высшее учебное заведение, быть успешными студентами.

Ключевые слова: обучение старшеклассников физике, цифровые лаборатории, образовательные электронные ресурсы, ИКТ-компетентность

\section{Список литературы}

[1] Булин-Соколова Е.И., Хохлова Е.Н., Рудченко Т.А., Семенов А.Л. Формирование ИКТ-компетентности младших школьников: пособие для учителей. М.: Просвещение, 2012. $128 \mathrm{c}$.

[2] Верховиева М.О. Учебный физический эксперимент с использованием современного оборудования как средство повышения эффективности учебного процесса: дис. ... канд. пед. наук. СПб., 2015. 219 с.

[3] Гельфгат И.М., Генденштейн Л.Э., Кирик Л.А. Решения ключевых задач по физике для профильной школы. 10-11 классы. М.: Илекса, 2016. 288 с.

[4] Давыдов В.Н. Использование цифровой лаборатории «Архимед» для изучения эффекта Ребиндера на внеурочных занятиях // Физика в школе. 2019. № 6. С. 57-60.

[5] Давыдов В.Н., Яковлева Т.Г. Использование цифровой лаборатории в учебной проектной деятельности школьников // Физика в школе. 2020. № 8. С. 198-202.

[6] Евдокимова B.E. Формирование ИКТ-компетентности младших школьников // Наука и перспективы. 2017. № 1. URL: http://docplayer.ru/68477507-Formirovanieikt-kompetentnosti-mladshih-shkolnikov.html (дата обращения: 14.10.2019).

[7] Заболотний А.И., Ханнанов Н.К. Использование цифровой лаборатории от «Научных развлечений» в массовой школе и учреждении дополнительного образования // Физика в школе. 2015. № 8. С. 37-45.

[8] Колесникова В.И. ИКТ-компетенции учащихся как основа становления нового качества образования. URL: https:/gigabaza.ru/doc/23721.html (дата обращения: 14.10.2019). 
[9] Ларченкова Л.А. Образовательный потенциал учебных физических задач в современной школе: дис. ... д-ра пед. наук. СПб., 2014. 387 с.

[10] Поваляев О.А., Ханнанов Н.К., Хоменко С.В. Цифровая лаборатория по физике: базовый уровень: методическое руководство по работе с комплектом оборудования и программным обеспечением фирмы «Научные развлечения. М.: МАКС-СПЕЙС, 2013. $104 \mathrm{c}$.

[11] Подпрограмма формирования и развития ИКТ-компетентности обучающихся на ступени основного общего образования. URL: http://av.disus.ru/programma/19972961-podprogramma-formirovaniya-razvitiya-ikt-kompetentnosti-obuchayuschihsya-stupeniosnovnogo-obschego-obrazovaniya-podprogramma-formirovaniya-razv.php (дата обращения: 14.10.2019).

[12] Соколова Н.Ю. Исследование изотермического и адиабатного процессов с использованием цифровой лаборатории // Физика в школе. 2018. № 1. С. 51-54.

[13] Тищенко Л.В. Экспериментальный практикум по физике как средство обучения старшеклассников решению задач (углубленный уровень) // Азимут научных исследований: педагогика и психология. 2018. Т. 7. № 2 (23). С. 279-286

[14] Федеральный государственный образовательный стандарт среднего общего образования Российской Федерации (утвержден Приказом Минобрнауки России от 17 мая 2012 г. № 413. В ред. Приказов Минобрнауки России от 29.12.2014 г. № 1645, от 31.12.2015 г. № 1578, от 29.06.2017 г. № 613). URL: https://classinform.ru/fgos/ 1.4-srednee-obshchee-obrazovanie-10-11-class.html (дата обращения: 14.10.2019).

[15] Федорова Н.Б., Кузнецова О.В., Огнева М.А. Методика организации исследовательского мини-проекта с использованием цифровой лаборатории как средство формирования ключевых компетенций на уроках физики // Физика в школе. 2020. № 1. C. $38-43$.

[16] Харлова E.B. Формирование у обучающихся ИКТ-компетентности. URL: https:// pedsovet.su/publ/47-1-0-4671 (дата обращения: 14.10.2019).

[17] Kornilov V.S., Lvova O.V., Obolensky I.S. Teaching physics students of humanitarianoriented groups in the Middle Years Programme (basic school) of the International Baccalaureate // Вестник Российского университета дружбы народов. Серия: Информатизация образования. 2019. Т. 16. № 3. С. 270-280.

\section{История статьи:}

Дата поступления в редакцию: 15 ноября 2019 г. Дата принятия к печати: 20 декабря 2019 г.

\section{Для цитирования:}

Kornilov V.S., Khanina I.A. Development of ICT competence in high school students when teaching physics using digital laboratories // Вестник Российского университета дружбы народов. Серия: Информатизация образования. 2020. Т. 17. № 2. С. 146-152. http://dx. doi.org/10.22363/2312-8631-2020-17-2-146-152

\section{Сведения об авторах:}

Корнилов Виктор Семенович, доктор педагогических наук, кандидат физико-математических наук, профессор, профессор кафедры информатизации образования Московского городского педагогического университета. E-mail: vs_kornilov@mail.ru

Ханина Ирина Александровна, учитель информатики школы № 1494 города Москвы. E-mail: irakhanina001@mail.ru 